\title{
APPLICATION OF TEMPERATURE CONTROL SYSTEMS AT THE CATALYST ACTIVATION STEP IN THE METHANOL TESTPLANT
}

\author{
Arya Bhaskara Adiprabowo, Astri Pertiwi, Nurdiah Rahmawati, Frendy Rian Saputro, \\ Novio Valentino, Hana Nabila Anindita, Desy Septriana \\ Center of Technology for Energy Resources and Chemical Industry, \\ Agency for the Assessment and Application of Technology \\ e-mail: arya.bhaskara@bppt.go.id
}

\begin{abstract}
Catalyst activation is an important step in methanol synthesis process, achieved by the reduction of $\mathrm{CuO}$ precursor producing $\mathrm{Cu}^{0}$ active sites. Testplant's temperature operation shall be maintainted at $220^{\circ} \mathrm{C}$ in order to maximize the $\mathrm{CuO}$ reduction process in the catalyst activation step. A temperature control system shall be applied in methanol testplant to maintain the temperature during reduction process, due to sensitivity of reduction process to temperature variation and possibility of disturbance such as change in gas flow rate which could affects the operating temperature. Temperature control systems are tested by using step response at the desired setpoint, which is $220^{\circ} \mathrm{C}$ at pre-heater and reactor and $60^{\circ} \mathrm{C}$ at sampling line. The tests are conducted by changing the setpoint value at temperature controller and previously stable flow gas in the system (disturbance rejection). The temperature control system proved to be able to response well during the test. In the end, methanol is produced from syngas, indicating catalyst activation success.
\end{abstract}

Keywords: Catalyst Activation; Methanol Testplant; Temperature Controller

\section{INTRODUCTION}

A control system is defined as a configuration of tools to control the input from a system, plant, or machine to establish desired outcome that may change during a chemical reaction or process. In general, the control system is structured by the following components.

a. Sensor

Sensor is one of the components in the control system that measured process variables and send the measurement signal as an input to the controller. Type of sensor that mounted on a control system depends on process variables that needs to be monitored/controlled, such as pressure, temperature, etc.

b. Controller

Controller is a component in the control system which acted as the brain, by receiving input from the sensor and providing control signal to the actuator so that the process variable can be corrected in accordance with its setpoint. Control algorithm is embedded inside the controller which suit its process characteristics, such as on-off, ProportionalIntegral-Derivative (PID), etc.

c. Actuator
Actuator is a component in the control system that serves as "hands",that control the process variable directly by receiving control signals from the controller and regulating manipulated variables, such as flow rate, electric current, etc.

Today, control systems have been implemented in various process industries with various advantages such as quality control of process output, improvement of process performance, and plant operation safety. One of the objectives of process control is establishing stable plant operation and meeting product specifications. If those process variables in a plant are under controlled, the process can operate more smoothly and steadily, while external interference from the outside, such as changes in flow rate and temperature changes can be controlled properly [1].

Methanol is a compound that has been widely known as an intermediate product both in the fuel and chemical industries, including in the production of acetic acid, dimethyl ether (DME), formaldehyde, methyl tertiary butyl ether (MTBE), polyvinyl, polyester, and others. Future domestic methanol requirement in 2021 are predicted to reach 871,000 tons per year, yetcurrent domestic 
production is only 330,000 tons per year by PT. Kaltim Methanol Industri. This encourages efforts to develop methanol production in order to meet domestic needs.

Currently, methanol on an industrial scale is produced using natural gas as a raw material. In an effort to diversify raw material sources as well as anticipate future natural gas scarcity, methanol production developed with syngas (synthesis gas) as raw materials obtained from biomass waste through the gasification process. The reaction of methanol synthesis involves catalyst, in this case, used copper-zinc oxide catalyst with aluminum oxide $\left(\mathrm{Cu} / \mathrm{Zn} / \mathrm{Al}_{2} \mathrm{O}_{3}\right)$ as support material, with operating conditions at pressures of 5-10 MPa (50-100 bar) and temperatures of $473-523 \mathrm{~K}\left(200-250^{\circ} \mathrm{C}\right)$ [2]. The similarities of methanol synthesis reactions are as follows.

$$
\begin{gathered}
\mathrm{CO}+2 \mathrm{H}_{2} \rightleftarrows \mathrm{CH}_{3} \mathrm{OH} \\
\Delta \mathrm{H}_{298 \mathrm{~K}, 5 \mathrm{MPa}}=-90.7 \mathrm{kJmol}^{-1} \\
\mathrm{CO}_{2}+3 \mathrm{H}_{2} \rightleftarrows \mathrm{CH}_{3} \mathrm{OH}+\mathrm{H}_{2} \mathrm{O} \\
\Delta \mathrm{H}_{298 \mathrm{~K}, 5 \mathrm{MPa}}=-40.9 \mathrm{kJmol}^{-1}
\end{gathered}
$$

The presence of $\mathrm{Cu}$ catalyst can also trigger water-gas shift (WGS) reaction with the following reaction equation [3].

$$
\begin{array}{r}
\mathrm{CO}+\mathrm{H}_{2} \mathrm{O} \rightleftarrows \mathrm{CO}_{2}+\mathrm{H}_{2} \\
\Delta \mathrm{H}_{298 \mathrm{~K}, 5 \mathrm{MPa}}=-49.8 \mathrm{kJmol}^{-1}
\end{array}
$$

Before it can be used in methanol synthesis, the catalyst must be activated first to convert the $\mathrm{CuO}$ metal oxide precursor into a Cu${ }^{0}$ active site. One of the catalyst activation method that used is passing the reducing gas medium continuously to the catalyst bed at a certain temperature [4]. During the reduction process, water molecule $\left(\mathrm{H}_{2} \mathrm{O}\right)$ will be formed, which is can be used as an indicator of the ongoing catalyst activation process. The reducing gas that can be used are hydrogen or hydrogen mixture in nitrogen with a temperature between $200-250^{\circ} \mathrm{C}$. The $\mathrm{CuO}$ catalyst reduction reaction equation is described as follows.

$$
\mathrm{CuO}+\mathrm{H}_{2} \rightarrow \mathrm{Cu}^{0}+\mathrm{H}_{2} \mathrm{O}
$$

In methanol testplant testing activities, a reduction temperature of $220^{\circ} \mathrm{C}$ is selected with hydrogen as reducing gas. At this temperature, as much as $42 \%$ of $\mathrm{CuO}$ has been reduced, which is the highest percentage compared to $200^{\circ} \mathrm{C}$ and $170^{\circ} \mathrm{C}$ which is only $28 \%$ reduced $\mathrm{CuO}$. Higher reduced percentage of $\mathrm{CuO}$ will directly affect successful catalyst activity [5].

During the reduction process, the temperature shall be maintained stable at its setpoint in order to support reduction process in optimum. Therefore, the temperature of the reducing gas (hydrogen) to the reactor and the temperature inside the reactor shall be controlled. In this paper, one of the main focus is on the application of temperature control systems during the catalyst reduction process in a methanol testplant located in the Laboratory of the Center of Technology for Energy Resources and Chemical Industry, the Agency for the Assessment and Application of Technology (PTSEIK-BPPT). In this paper, implementation of how temperature control in methanol testplant during catalyst activation and plant operation is discussed and further analysed from the control system stability criteria. Reduction process is said to be successful if water production is decreasing in during the reduction process, according to the reaction equation (4), and activated catalysts can convert syngas into methanol compounds.

\section{MATERIAL AND METHOD}

\section{A. Methanol Testplant}

A methanol test plant has been built in PTSEIK - BPPT Laboratory located in Energy Building 625 Puspiptek Serpong area, functioning as a research facility for methanol synthesis from syngas as the result of biomass gasification and to test the performance of catalysts in methanol synthesis that is under research. The overall flowchart of the methanol synthesis process on the methanol test plant is shown in Figure 1 below. 


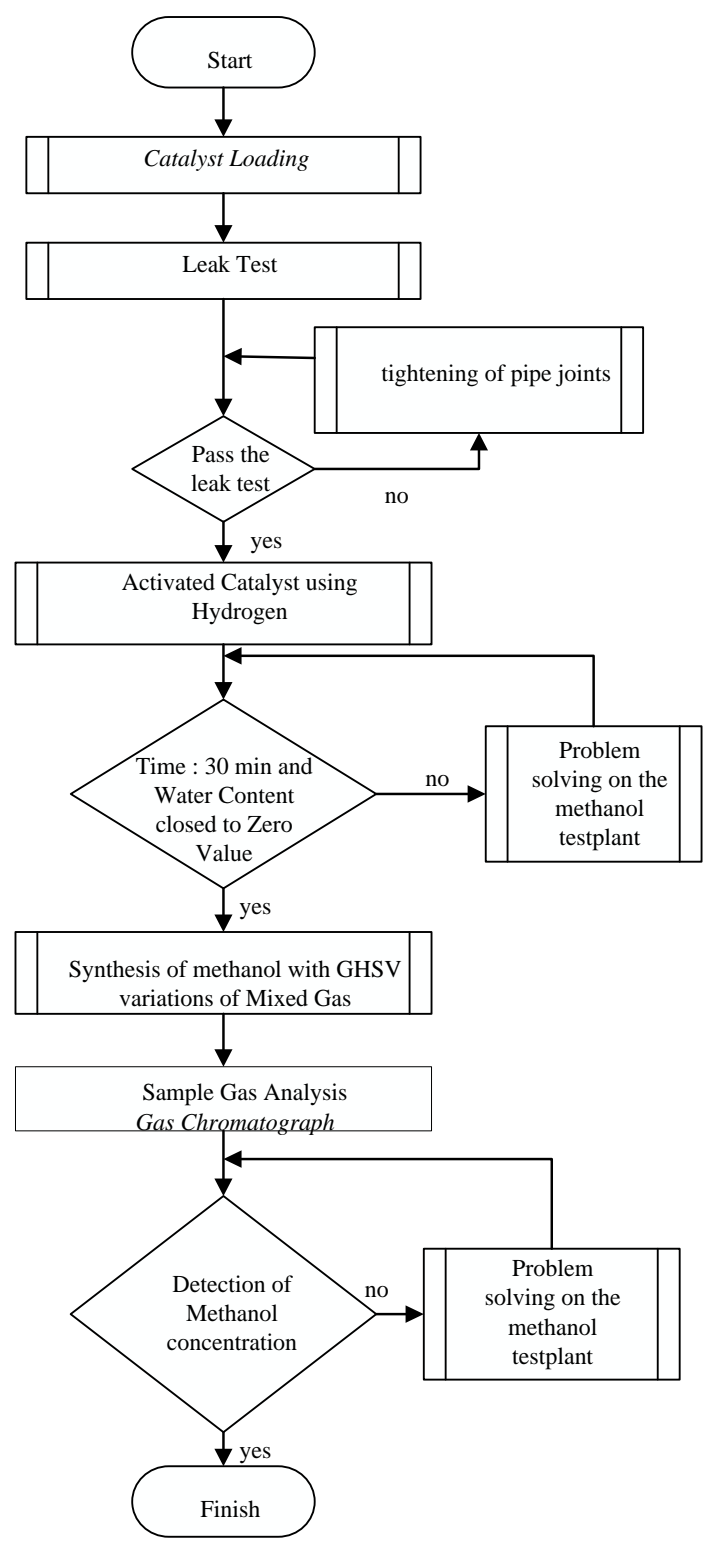

Figure 1. Methanol Synthesis Flowchart in Methanol Testplant

The gas used in the methanol test plant operation is divided into 3 (three) groups based on their function, which is (1) nitrogen used for leak test purposes, (2) hydrogen as a reducing gas during catalyst activation, and (3) mixed gas model as the syngas used for feed of methanol synthesis that consists of carbon monoxide $(\mathrm{CO})$, carbon dioxide $\left(\mathrm{CO}_{2}\right)$ and hydrogen $\left(\mathrm{H}_{2}\right)$ with a certain composition. The composition and specifications of the gas can be seen in Table 1 and Table 2.
Table 1

Hydrogen and Nitrogen Gas Specification

\begin{tabular}{lcc}
\hline & Hidrogen & Nitrogen \\
\hline Pressure & $150 \mathrm{bar}$ & $150 \mathrm{bar}$ \\
Purity & $>99.99 \%$ & $>99.99 \%$ \\
$\mathrm{O}_{2}$ & $<10 \mathrm{ppm}$ & $<3 \mathrm{ppm}$ \\
$\mathrm{H}_{2} \mathrm{O}$ & $<10 \mathrm{ppm}$ & $<2 \mathrm{ppm}$ \\
$\mathrm{H} / \mathrm{Cs}$ as $\mathrm{CH}_{4}$ & $<5 \mathrm{ppm}$ & $<$ n.d \\
\hline
\end{tabular}

Table 2

Mixed Gas Specification

\begin{tabular}{ll}
\hline WT/Pressure & $150 \mathrm{~kg} / \mathrm{cm}^{2}$ \\
\hline $\mathrm{CO}$ & $29.5 \%$ \\
\hline $\mathrm{H}_{2}$ & $59.2 \%$ \\
\hline $\mathrm{N}_{2}$ & Balance \\
\hline
\end{tabular}

\section{B. Leak Test and Catalyst Activation}

Leak tests are performed to ensure safety during the operation of the methanol test plant. According to ASME B31.3, pneumatic leak test method is used in this testplant, because the fluid involved in methanol synthesis is a gas. Another fluid medium, such as using of water or other incompressible fluids is avoided because it can damage the catalysts or reactors.

In this leak test, nitrogen gas is used which is inert, non-flammable, and non-toxic. The leak test was carried out at a pressure of 1.1 - 1.33 times the design pressure of the methanol test plant, which is 16.67 bar. Therefore, the pressure test used must be in the range of $18.34-22.17$ bar, in this case, the pressure of 20 bar is chosen. The leak test is carried out for at least 10 minutes. The methanol test plant is declared to have passed the leak test if no leakage is found visually at all joints or connections, and no pressure drop is found [6].

After leak test is done successfully, the activation process is then carried out. The pressure of hydrogen gas from the cylinder is regulated using a pressure regulator for stable operation at the desired pressure, and the pre-heater line temperature is increased to $220^{\circ} \mathrm{C}$. Next, hydrogen gas entered the reactor and reduced the catalyst so that the catalyst activation process is began. The reactor temperature during the activation process was maintained at $220^{\circ} \mathrm{C}$, which is the optimum temperature for the activation of the $\mathrm{Cu}$ catalyst. Higher temperature can damage the catalyst [7]. 
M.I.P.I Vol.15, No 1, April 2021 - (1-15)

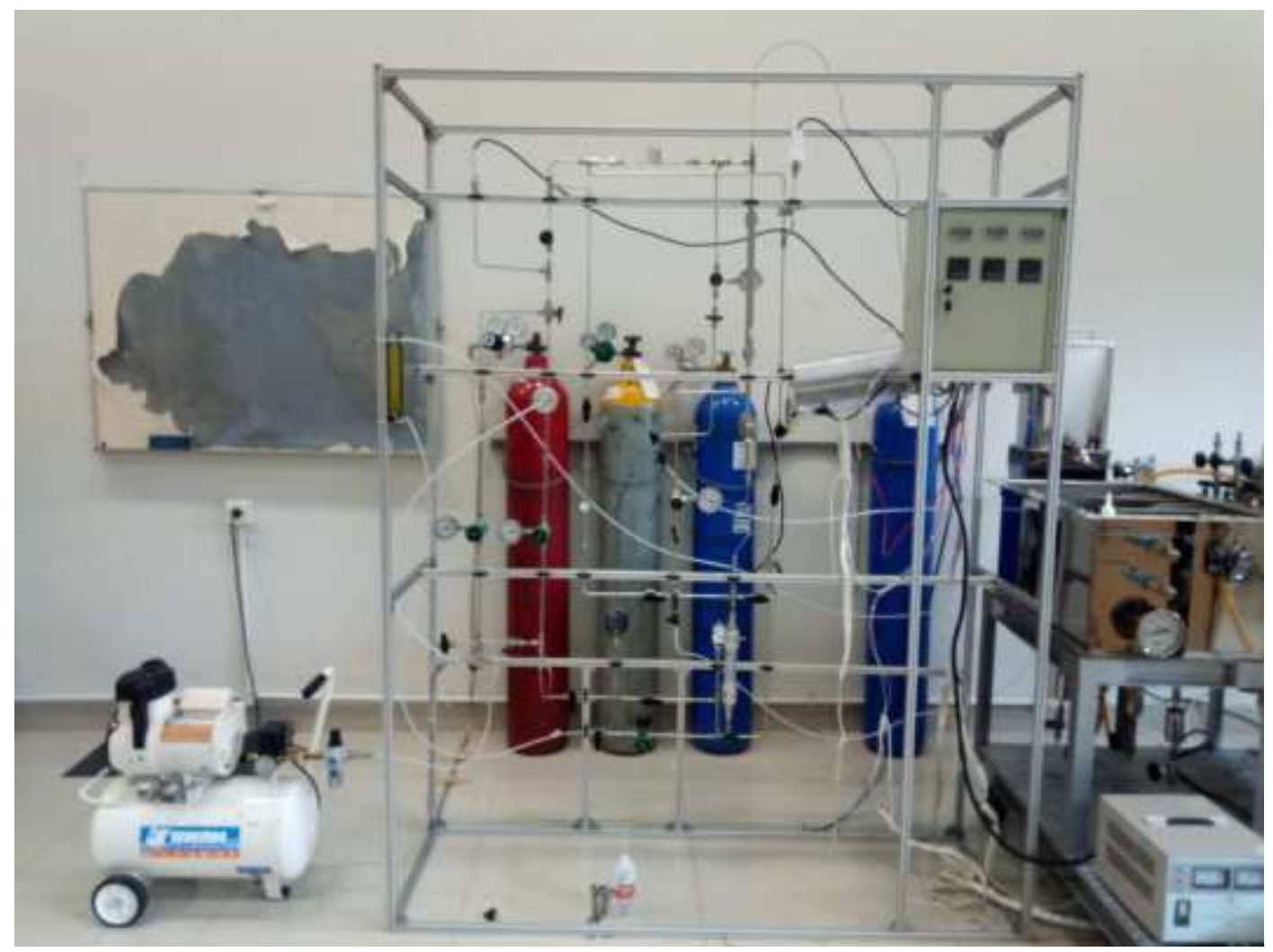

Figure 1. Methanol Testplant

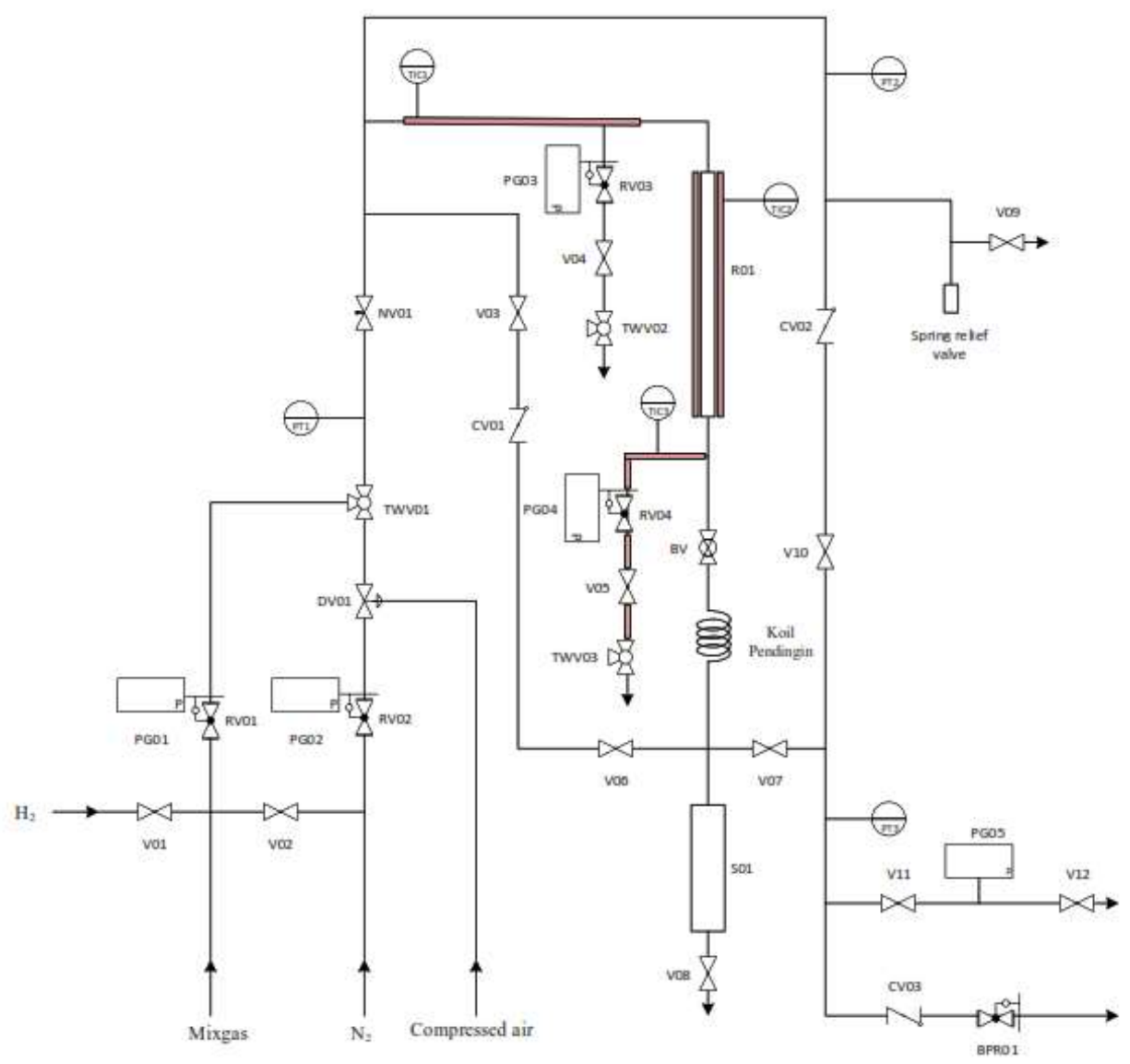

Figure 2.

P\&ID Methanol Testplant 
The catalyst activation process is carried out for 30 hours. The water content of the output gas from the reactor is recorded periodically by moisture analyzer. If the water content on the output gas is close to zero, then the catalyst activation process has been completed.

Table 3.

Components of Methanol Testplant Instrumentation

\begin{tabular}{cl}
\hline No & \multicolumn{1}{c}{ Instrument } \\
\hline 1 & Pressure Regulator \\
2 & Pressure Transmitter \\
3 & Ball Valve \\
4 & Three Way Valve \\
5 & Needle Valve \\
6 & Thermocouple \\
7 & Band Heater \\
8 & Pressure Gauge/Calibrator \\
9 & Temperature Controller \\
10 & Hyper Glass Indicator \\
\hline
\end{tabular}

The instrumentation and control system in the methanol testplant plays a critical role to obtain test data, measure process variables, and control temperature. The instrumentation architecture system for the methanol testplant is shown in Figure 4 below.

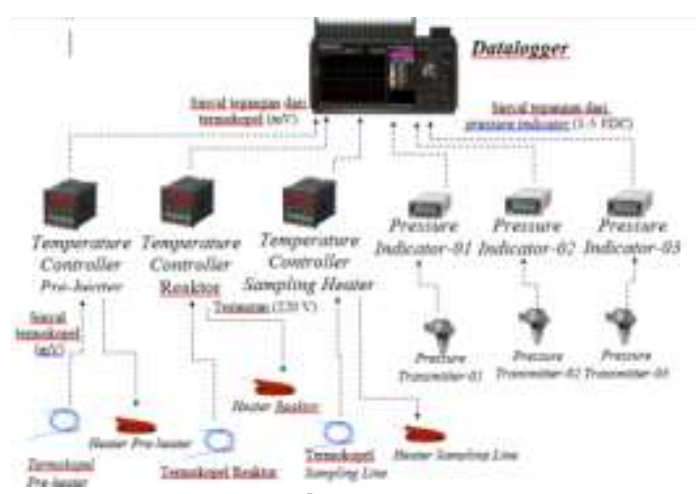

Figure 3.

Methanol Testplant Instrumentation Architecture System

The pressure is measured at three points, which is at gas feed inlet, reactor, and exhaust line from the reactor. Pressure measurement are done by using a pressure transmitter which has a value of $0.5 \%$ of full scale. The data from each pressure transmitters is converted into an electric current with a range of 1-5V DC (direct current), and the pressure data is used as pressure data on the pressure monitor located on the control panel.

\section{Instrumentation System on Methanol Test Plant}

The methanol test plant piping and instrumentation diagram (P\&ID) is shown in Figure 3, and the list of methanol test plant constituent components is displayed in Table 3

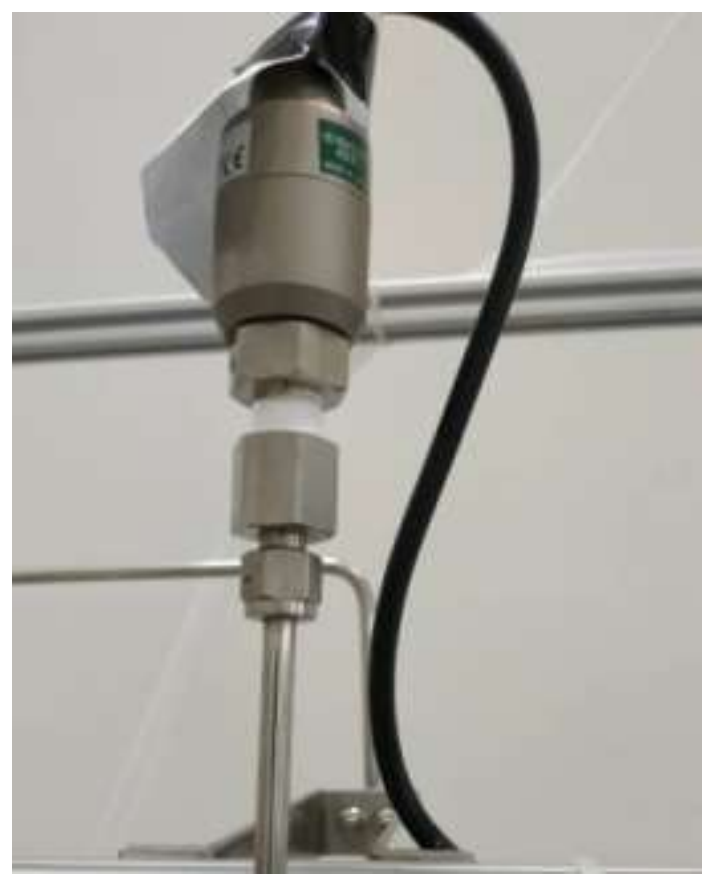

Figure 5.

Installation of 4Pressure Transmitter on Methanol Testplant

To measure the temperature inside the methanol testplant, a thermocouple is used because it requires a wide temperature measurement range. In addition, the thermocouple was chosen because it does not require self-powered power, withstands extreme operating conditions, and is relatively easier to obtain than other temperature sensors such as resistance temperature detectors (RTD) and thermistors [8].

Table4.

Instrumentation System on Methanol Testplant [9]

\begin{tabular}{lccl}
\hline \multicolumn{1}{c}{ Type } & Quantity & $\begin{array}{c}\text { Measurement } \\
\text { Range }\end{array}$ & Display \\
\hline $\begin{array}{l}\text { Pressure } \\
\text { Transmitter } \\
\text { Thermocouple }\end{array}$ & 3 & $0-3.5 \mathrm{MPa}$ & $\begin{array}{l}\text { Pressure } \\
\text { Indicator }\end{array}$ \\
& 3 & $0-1,200^{\circ} \mathrm{C}$ & $\begin{array}{l}\text { Temperature } \\
\text { Controller }\end{array}$ \\
\hline
\end{tabular}

Temperature is measured at three lines, such as feed gas inlet, reactor, and gas sample take off. The measurement results are displayed on temperature controllers in the control panel. Band heaters are installed on those three lines in order to control and 
maintain temperature operating conditions in the test plant. Electric current is flowing through the wire filament in the band heater, thus transferring heat energy into the pipe/reactor. Hence, it functioned as an actuator in the temperature control system loop. A temperature controller is used to receiving measurement signals from the thermocouple, displaying temperature measurement results, and sending control signals to the band heater. Heat resulted by the electron flows from the temperature controller's control signal that resisted by the heater conductor ends will be converted to heat energy. Table 5 shows the methanol test plant's band heater specification.

Table 5.

Band Heater Specification

\begin{tabular}{cc}
\hline Heater Type & $\begin{array}{c}\text { Mantle Heater } \\
\text { Type 2-3 }\end{array}$ \\
\hline Power & 150 watt \\
Voltage & 110 volt \\
Max. Temperature & $450^{\circ} \mathrm{C}$ \\
\hline
\end{tabular}

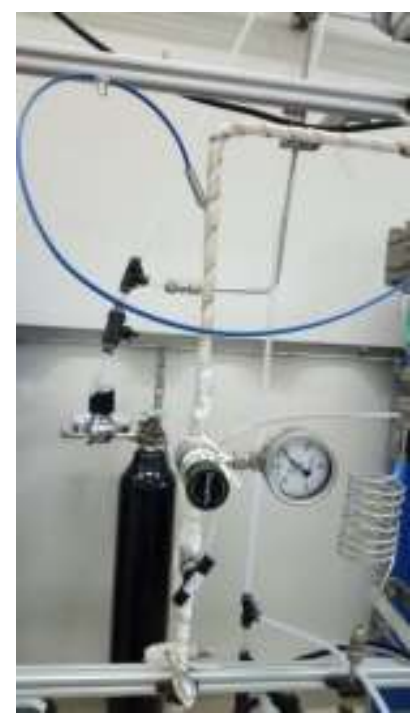

Figure 5.

Thermocouple and Band Heater installation in Methanol Testplant

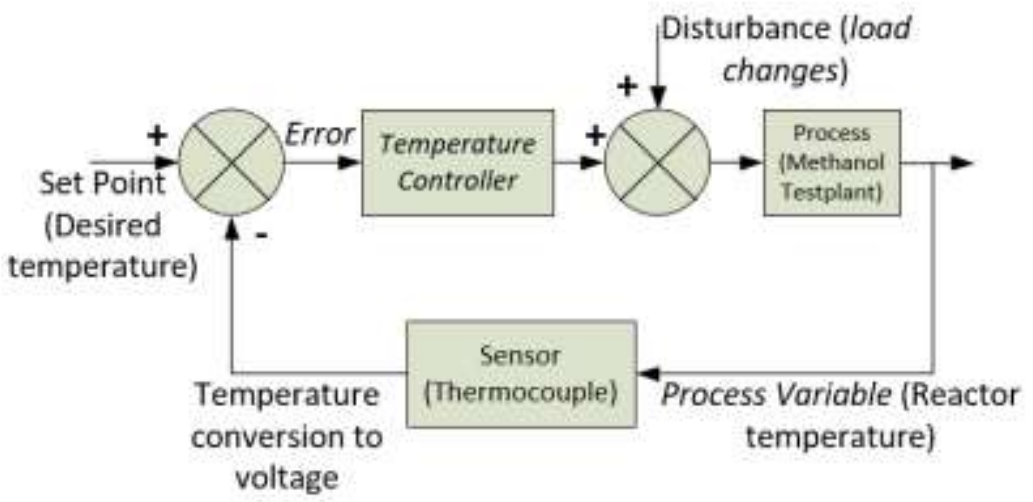

Figure 6

Temperature Control System Block Diagram for Methanol Testplant 


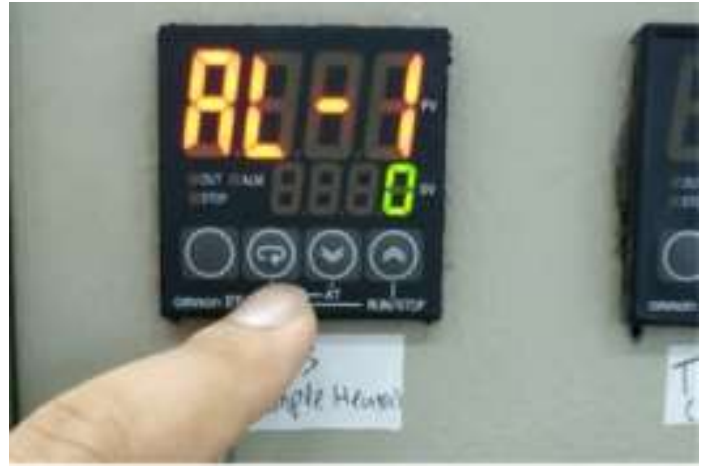

Figure 7.

Operation of Temperature Controller in Methanol Testplant

\section{Methanol Testplant Temperature Control System}

The temperature setpoint maintained in this methanol test plant is the temperature of catalyst activation, which is $220^{\circ} \mathrm{C}$. This setpoint is set inside the temperature controller through a keypad as shown in Figure 8. Voltage signals from the thermocouple are sent as process variables to the temperature controller. Control signals then sent by the temperature controller, as a product of calculation between the temperature setpoint of controller and process variable, to the band heater. Thus, generated heat from the band heater will increase the temperature in methanol test plant, such as pre-heater line, reactor, and sampling line.

The heat resulted from the temperature increment will be read again by the thermocouple. This process is continuously repeated through a cycle until the process variable is the same as the setpoint, which means the error is not detected anymore by the temperature controller. Thus, temperature process variable has achieved the desired operating value by the result of the temperature controller action. Figure 7 shows the temperature control system block diagram.

PID (Proportional Integral Derivative) is used as a temperature control system's algorithm. The PID control equation in time domain relationship is given below [10].

$$
u(t)=K p e(t)+K_{i} \int_{0}^{t} e(t) d t+K_{d} \frac{d e(t)}{d t}(5)
$$

Error in the control system will be multiplied by the gain in the proportional $(P)$ element, thus giving correction of process variable deviation against the setpoint. Derivative (D) element will give an underdamped response of the control system so that undesired overshoot response will be reduced. In the catalyst reduction process, there is a temperature maximum limitation $\left(250^{\circ} \mathrm{C}\right)$ for the catalyst in order to keep its function.

Undesired process variable overshoot in catalyst reduction process will be eliminated by the underdamped response of the derivative (D) component in the PID control algorithm. On the other hand, offset (steadystate deviation between process variable and setpoint) will be eliminated by the integral (I) component. This integral component is also used to adjust the temperature to reach a steady-state condition faster. Parameter of PID control, which is set on the controller, is denoted by a non-negative coefficient (Kp for $\mathrm{P}, \mathrm{Ki}$ for $\mathrm{I}$, and $\mathrm{Kd}$ for $\mathrm{D}$ ) or by another coefficient that stated in the time domain, such as Ti for I and Td for D. PID tuning is done for determining its control parameters [11].

Automatic tuning feature inside these temperature controllers can be used to determine the PID control coefficient. The automatic tuning feature can be accessed by using the switch in front of the temperature controller [12]. The automatic tuning method used in this temperature controller is based on transient response and feedback relay. Automatic tuning is done while the process variable is in steady condition, while it might be below or above its setpoint [13].

The temperature controller shall be tested in order to support the catalyst activation process properly. A flowchart for testing the controller is shown in Figure 9 below.

\section{RESULT AND DISCUSSION}

Automatic tuning is done to obtain proportional $(\mathrm{P})$, integral $(\mathrm{I})$, and derivative (D) coefficients that set on the PID controller. Table 6 shows PID control coefficients (Kc for $\mathrm{P}$, Ti for I, and Td for D) for each temperature controllers after automatic tuning is done.

Table 6.

PID Control Coefficient in Methanol

Testplant's Temperature Control System

\begin{tabular}{lccc}
\hline $\begin{array}{c}\text { Temperature } \\
\text { Controller }\end{array}$ & $\begin{array}{c}\mathbf{P} \\
\mathbf{( K c )}\end{array}$ & $\begin{array}{c}\mathbf{I} \\
\text { (Ti) }\end{array}$ & $\begin{array}{c}\mathbf{D} \\
\text { (Td) }\end{array}$ \\
\hline TIC-1 (Reactor) & 11.0 & 59 & 10 \\
TIC-2 (Pre-Heater) & 10.3 & 42 & 7 \\
TIC-3 (Sampling Line) & 7.7 & 36 & 6 \\
\hline
\end{tabular}

Datalogger is used to observe and record temperature control system performance and its process variable trends during the commissioning of the plant. 


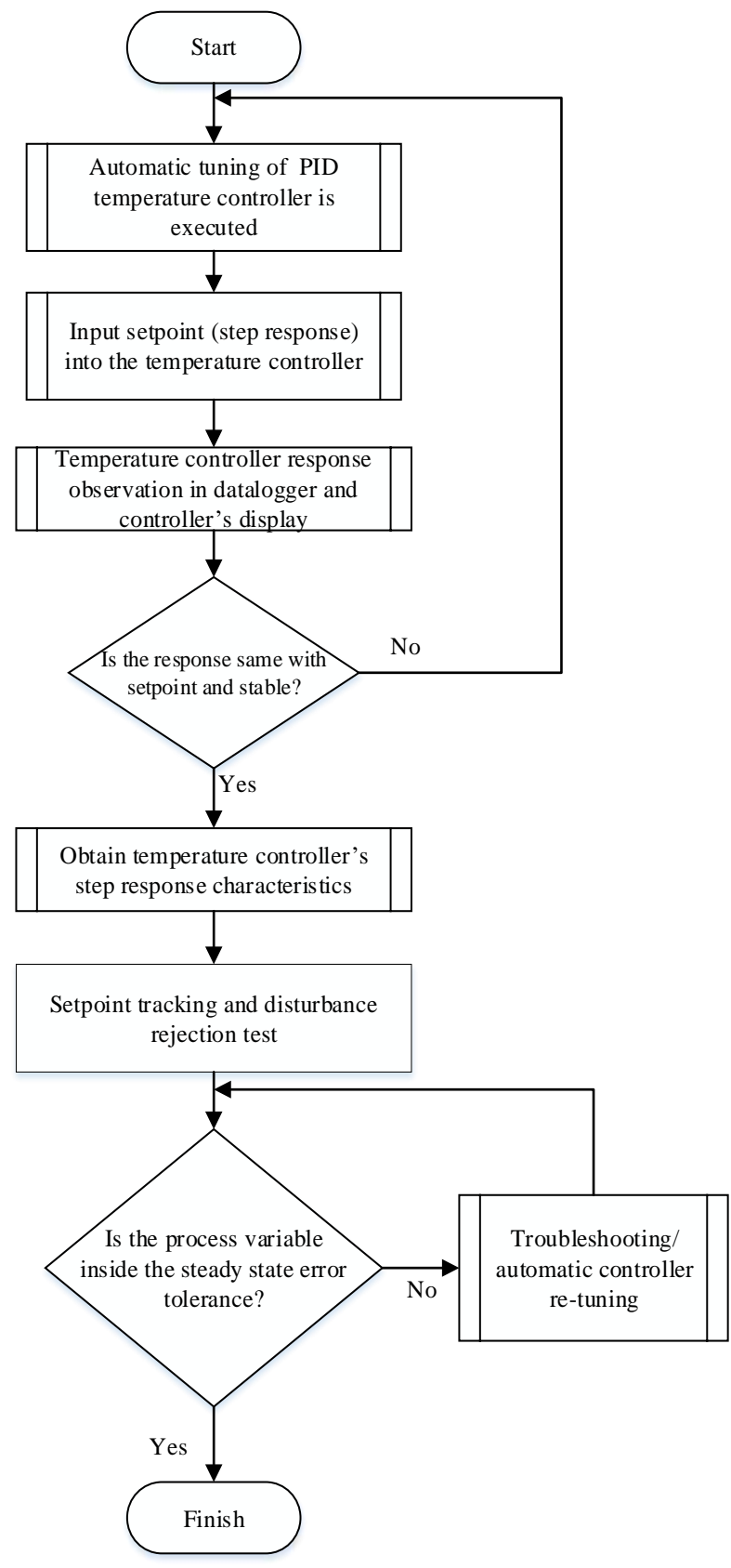

Figure 8

Temperature Controller Testing Flowchart

\section{A. Temperature Control System Step Response Analysis}

The step response is given as an input to the temperature controller, with $220^{\circ} \mathrm{C}$ for the pre-heater \& reactor section and $60^{\circ} \mathrm{C}$ for the sampling line section as the controller's setpoint. Second-order response with overdamped characteristic is shown as the result of step response input to the system. Dynamic criteria of step response characteristic are described as follows [13].

1) Rise Time (Tr), is defined as the time required for the process variable to reach a steady-state condition.
2) Time to First Peak (Tp), is defined as the time required for the process variable to reach its first maximum value.

3) Settling Time (Ts), is defined as the time required for the process variable to reach within $\pm 2 \%$ range of setpoint.

4) Overshoot, defined as the ratio of system response's peak value to the setpoint.

The system's response can be observed in the temperature controllers or datalogger after a step input is given. Figure 10 represent the step input response of each temperature controller (reactor, pre-heater, and sampling line) respectively. Datalogger recording result is depicted in Table 7.

Table 7.

Step Input Response of Temperature Control System

\begin{tabular}{cccc}
\hline $\begin{array}{c}\text { Temperature } \\
\text { Controller }\end{array}$ & $\begin{array}{c}\text { TIC-1 } \\
\text { (Reactor) }\end{array}$ & $\begin{array}{c}\text { TIC-2 } \\
\text { (Pre- } \\
\text { Heater) }\end{array}$ & $\begin{array}{c}\text { TIC-3 } \\
\text { (Sampling) }\end{array}$ \\
\hline $\begin{array}{c}\text { Setpoint }\left({ }^{\circ} \mathrm{C}\right) \\
\text { Initial }\end{array}$ & 220 & 220 & 60 \\
temperature & 24.2 & 24.3 & 27 \\
$\left({ }^{\circ} \mathrm{C}\right)$ & & & \\
$\operatorname{Tr}(\mathrm{s})$ & 432 & 364 & 49 \\
$\operatorname{Ts}(\mathrm{s})$ & 482 & 448 & 92 \\
\hline
\end{tabular}

The overdamped response is shown by the temperature control system, which means there is no overshoot. Data obtained from Table 7 is showing that TIC-2 reached settling time in 482 seconds, TIC- 1 in 448 seconds, and TIC-3 in 92 seconds.

Despite having the same setpoint, the settling time of TIC-2 is quicker than TIC-1 because TIC-1 has a greater heat requirement than TIC-2. TIC-1 controls reactor temperature with $170 \mathrm{~mm}$ diameter and has a catalyst inside it, thus has a bigger surface area than TIC-2 (which has $6.35 \mathrm{~mm}$ diameter). TIC-3 can reach the settling time faster than TIC- 1 and 2 because the deviation between the setpoint and process variable is less than those controllers, and also has less heat requirement than those controllers.

Although settling time is achieved with slower time than underdamped response (with overshoot) characteristic, with no overshoot observed from step input to the temperature controller of the reactor (TIC-1), catalyst inside the reactor is protected from unnecessary heat spike that can be harmful to the catalyst. All those three temperature controllers are able to maintain the desired setpoint in a steady-state condition with relatively quick settling time. Thus, it can be concluded that automatic tuning of those PID controllers works properly. 

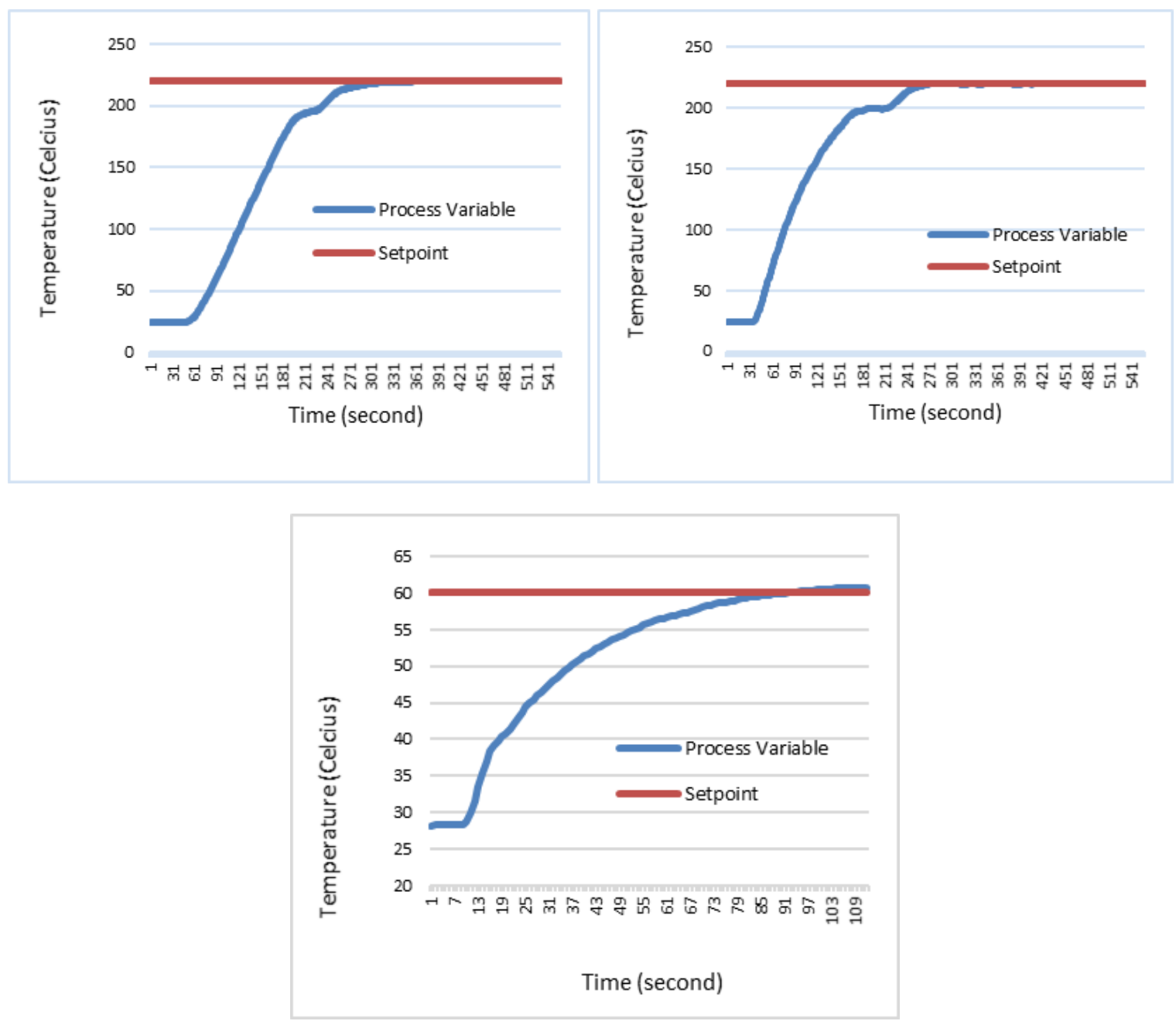

Figure 9.

Step Input Response of TIC-1 (left), TIC-2 (right), TIC-3 (bottom) Methanol Testplant

\section{B. Stability Test of Temperature Control System in Methanol Testplant}

Stability test shall be commenced after observation and analysis of step input response to temperature control system are done. Two kinds of stability test are done as follows.

\section{1) Setpoint Tracking}

The controller setpoint is changed in order to check if the temperature control system responding to adjust heat to the test plant. Setpoint is changed gradually in temperature controllers by $50^{\circ} \mathrm{C}$ step, which is $50^{\circ} \mathrm{C}$, $100^{\circ} \mathrm{C}, 150^{\circ} \mathrm{C}$, and $200^{\circ} \mathrm{C}$. Those ranges are chosen to match the methanol test plant operation temperature during catalyst activation accordingly. After process variables (actual temperature) reached their respective setpoint given in the temperature controller and in a steady-state condition, the setpoint in the temperature controller is increased immediately. Process variables response (shown with blue line) to setpoint increment (shown with red line) in each respective temperature controllers (TIC-1, TIC-2, and TIC-3) are shown in Figure 11. 

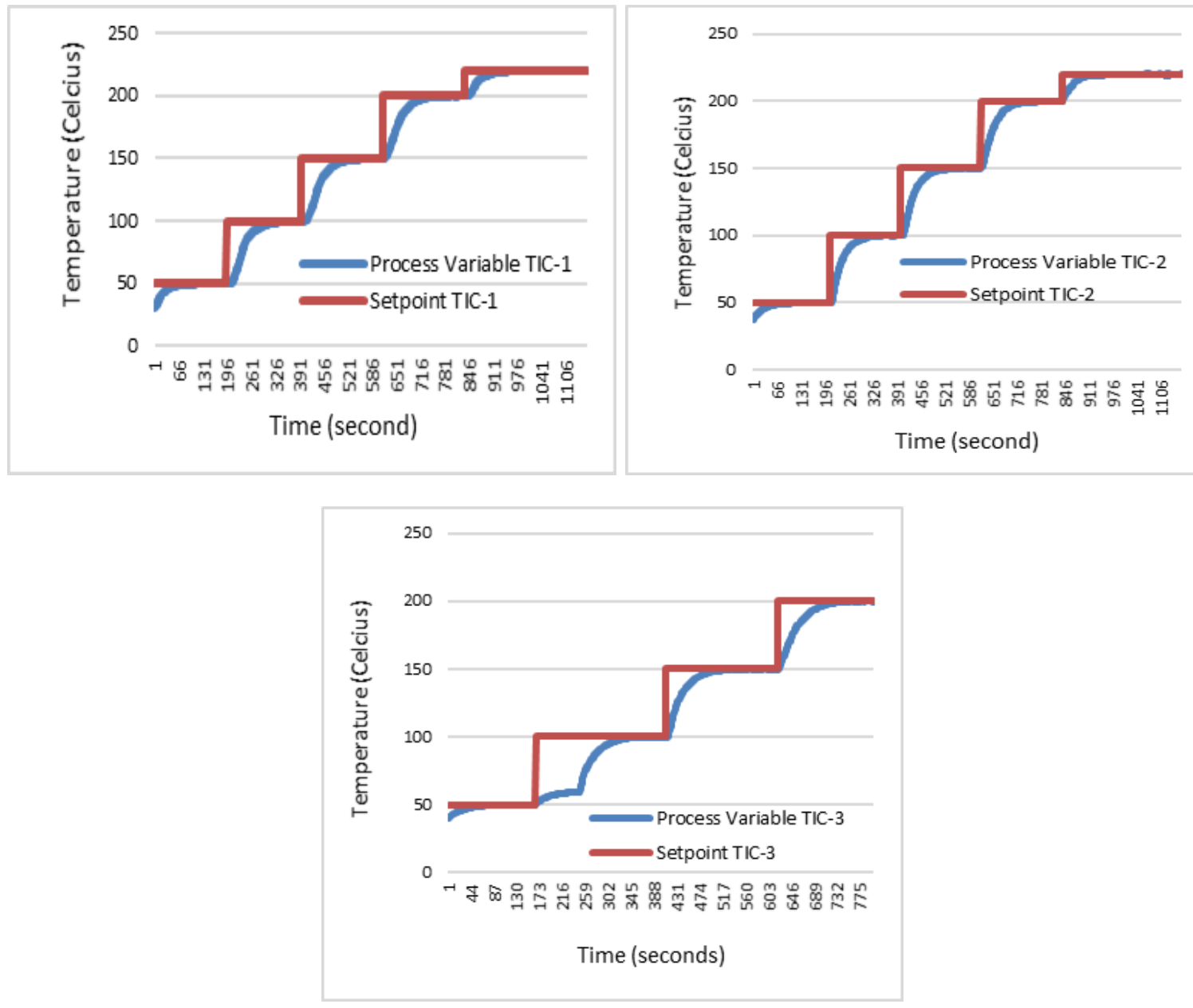

Figure 11.

TIC-1 (left), TIC-2 (right), TIC-3 (bottom) Response for Setpoint Change

Table 8.

Temperature Control System Response to Setpoint Changes

\begin{tabular}{cccc}
\hline $\begin{array}{c}\text { Temperature } \\
\text { Controller }\end{array}$ & $\begin{array}{c}\text { TIC-1 } \\
\text { (Reactor) }\end{array}$ & $\begin{array}{c}\text { TIC-2 } \\
\text { (Pre-Heater) }\end{array}$ & $\begin{array}{c}\text { TIC-3 } \\
\text { (Sampling) }\end{array}$ \\
\hline Ts (s) in $50^{\circ} \mathrm{C}$ & 77 & 82 & 67 \\
Ts (s) in $100^{\circ} \mathrm{C}$ & 120 & 96 & 80 \\
Ts (s) in $150^{\circ} \mathrm{C}$ & 107 & 86 & 78 \\
Ts (s) in $200^{\circ} \mathrm{C}$ & 90 & 78 & 78 \\
\hline
\end{tabular}

The time required for process variables to reach inside $2 \%$ steady-state error criteria (settling time) is shown in Table 8. As seen from the table above, TIC-1 needed a relatively longer time than other controllers (TIC-2 and TIC-3) to reach steady-state conditions due to greater heat requirements for heating the catalyst and gas inside the reactor. Setpoint change is handled well (within the $2 \%$ tolerance of error steady-state) and quickly (60-120 second maximum) by temperature controllers.

\section{2) Disturbance Rejection}

Load changes in a plant are one of a disturbance in the control system. In this case, the gas flowrate that flows to the methanol test plant is one of the loads. The gas flowrate in the methanol test plant is increased by using the flowmeter's valve to test the control system response to load changes. This load increment caused greater heat requirements than the previous condition. To retain gas flowrate temperature in the methanol test plant as the same as controller's set point, the heat shall be added to the methanol test plant in order to eliminate this disturbance. The temperature control system is considered performing well if the temperature can be maintained as per its setpoint during a load change. Testing will be done by introducing $50 \mathrm{ml} / \mathrm{min}$ gas flowrate gradually to the system by using a flowmeter. After the process variable reached steady-state condition, then the same quantity of flowrate is added again to the test plant. 


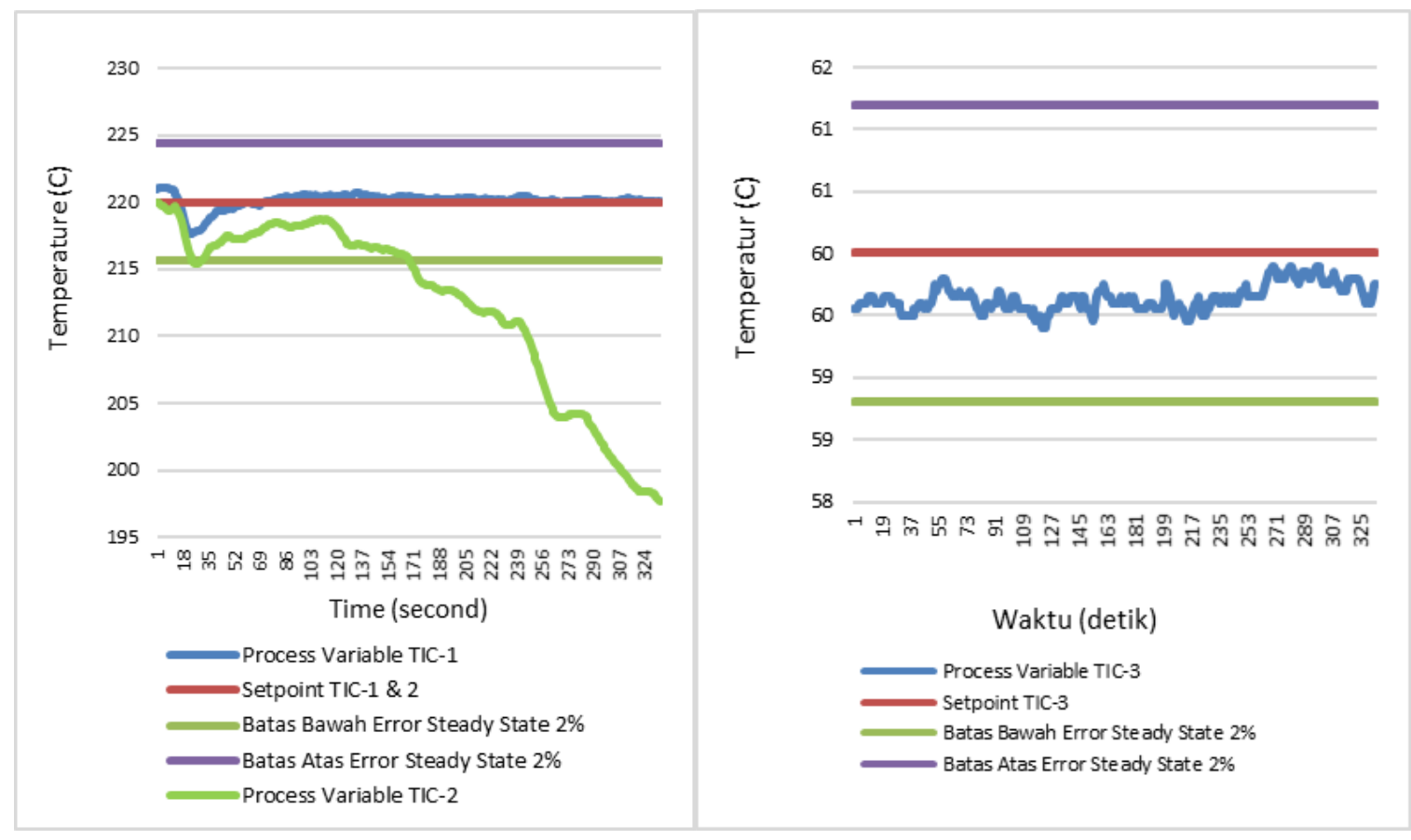

Figure 12.

Response of Flowrate Changes in TIC-1, TIC-2 (left) and TIC-3 (right) of Methanol Testplant at $50 \mathrm{ml} / \mathrm{min}$

Figure 12 shows the response of TIC-1 (blue line) and TIC-2 (green line) when experiencing gas flow rate changes with 50 $\mathrm{ml} /$ minute increment rate. The red line, light green line, and purple line indicate the temperature controller setpoint, lower limit, and upper limit of $2 \%$ steady-state error criteria, respectively.

TIC-1 response is going down for 30 seconds after the gas flowrate change, as shown by the blue line. However, it could respond well toward the change by adding extra heat to reactor's band heater, so the temperature could return immediately to the setpoint. Note that the disturbance caused by gas flowrate's load change remains within the $2 \%$ steady-state error criteria, indicating that TIC-1 is robust enough to fend off the load change to the system.

As for TIC-2, the green line in Figure 12 (left) shows that the process variable (temperature) keep decreasing after experiencing a flow rate change and cannot return to its previous set point. The process variable continues to fall below the $2 \%$ steady-state error criteria at 169 seconds, indicating a problem in TIC-2. This unstable control system was likely caused by autotuning in the PID controller, which less responsive toward load change in the system and therefore needs to be repeated.

Figure 12 (right) shows the TIC-3 response (blue line) toward the gas flow rate change in the amount of $50 \mathrm{ml} /$ minute. The red line, light green line, and purple line indicate the temperature controller setpoint, lower limit, and upper limit of steady-state error criteria $2 \%$, respectively. There is a slight variance in temperature, but still within the steady-state error criteria of $2 \%$. Hence, TIC-3 could control the temperature in the sampling line if flow rate load change occurred.

To overcome the problem in TIC-2, the autotuning need to be repeated with a flow rate being set at $50 \mathrm{ml}$ per minute. The difference of PID parameter on TIC-2 (preheater) before and after autotuning is shown in Table 9 as old and new parameters, respectively.

Table 9.

The Difference of PID Parameter on TIC-2 (Pre-heater)

\begin{tabular}{lccc}
\hline Parameter & $\mathbf{P}(\mathbf{K c})$ & $\mathbf{I}(\mathrm{Ti})$ & $\mathbf{D}(\mathbf{T d})$ \\
\hline Old & 10.3 & 42 & 7 \\
New & 6.5 & 15 & 3 \\
\hline
\end{tabular}

After the re-autotuning process, the load testing was conducted on TIC-2 and other temperature controllers. Figures 18 and 19 show the response of all temperature controllers toward the flow rate change. The initial gas flow rate was set at $50 \mathrm{ml} / \mathrm{min}$ and then increased gradually with the addition of $100 \mathrm{ml} / \mathrm{min}$ after being stable.

Figure 13 (left) shows that TIC-1 (reactor, red line) and TIC-2 (pre-heater, green line) 
can respond well toward the gradual flow rate change in the range of $100 \mathrm{ml} / \mathrm{min}$ to 500 $\mathrm{ml} / \mathrm{min}$. All the process variables are within the steady-state error criteria of $2 \%$. The fluctuation caused by the process variable has an insignificant effect and does not change the process temperature.

Figure 13 (right) shows that TIC-3 (sample line) also can respond well toward the gradual flow rate up to $500 \mathrm{ml} / \mathrm{min}$. The fluctuation of the process variables is still within the steadystate error criteria of $2 \%$.

From the description above, it can be concluded that all the temperature controllers used in the methanol test plant can respond well toward the disturbance rejection and ready to be utilized.
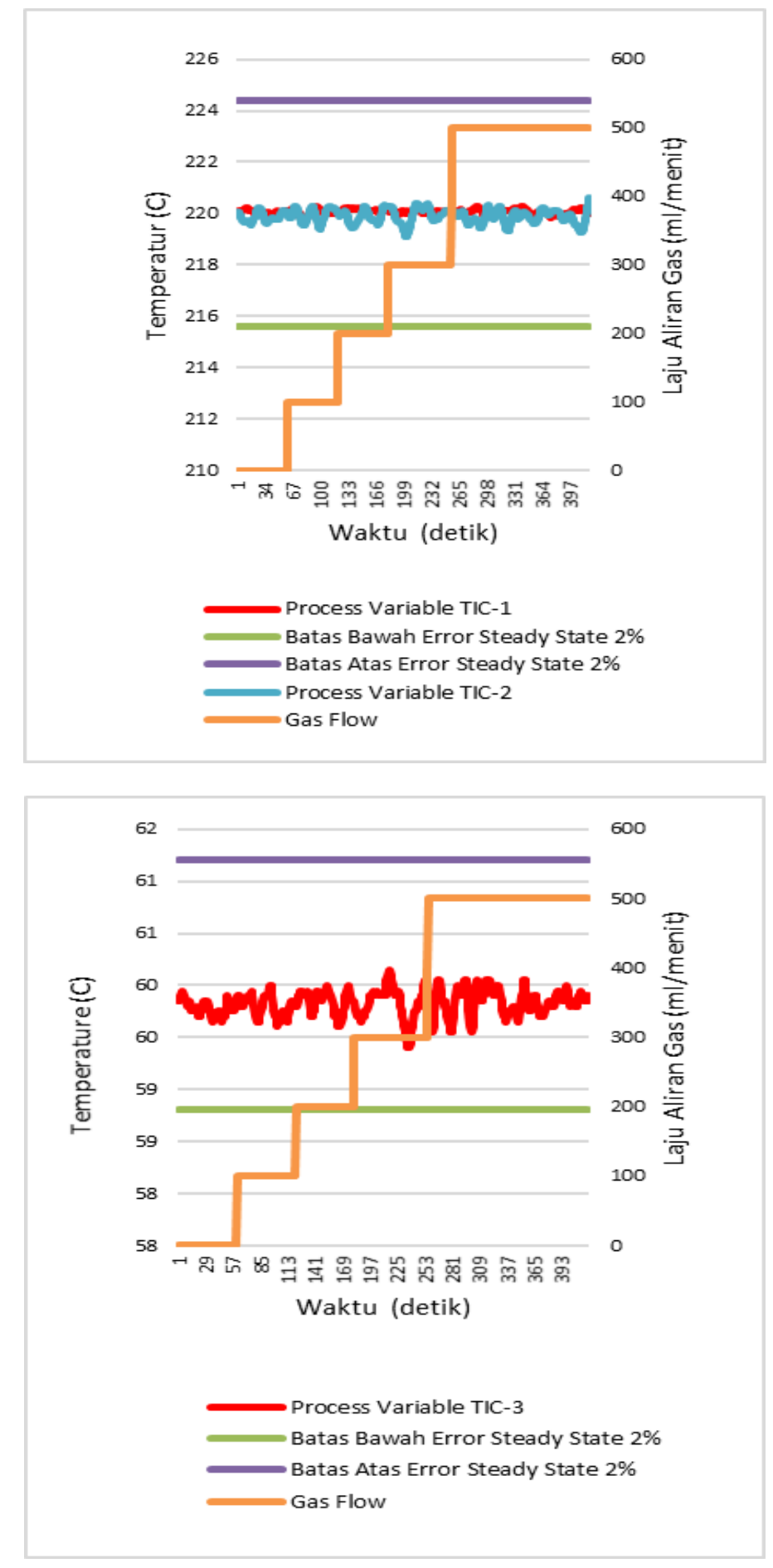

Figure 13.

TIC-1,TIC-2 (left) and TIC-3 (right) Controller Response of Load Change (per $50 \mathrm{ml} / \mathrm{min}$ ) 


\section{Water Content Analysis During Catalyst Activation Process}

Temperature controller performance was being tested toward the setpoint change and gas flowrate load change prior to its utilization on the catalyst activation process.

The catalyst activation process was started when the hydrogen gas began to flow into the methanol test plant. Hydrogen gas flow was adjusted using pressure regulator at $0,5 \mathrm{MPa}-\mathrm{g}$ and rotameter at $50 \mathrm{ml} / \mathrm{min}$ until being stable.

Hydrogen gas in the methanol test plant is heated by temperature controller setting at $220^{\circ} \mathrm{C}$. Hydrogen gas flows into the methanol test plant through the pre-heater line, reactor, and sampling line before released into the atmosphere.

A moisture analyser was connected online to the sampling line. It measured the water content, pressure, and temperature of the sample simultaneously.

Table 10 shows the process parameters on the catalyst activation.

The catalyst activation process was carried out for a total of 30 hours (1.800 minutes). It was conducted continuously for $6-7$ hours per day. The temperature of the methanol test plant and the sampling line was set at $220^{\circ} \mathrm{C}$ and $60^{\circ} \mathrm{C}$, respectively.

Table 10.

Process Parameters on the Catalyst Activation

\begin{tabular}{ll}
\hline \multicolumn{1}{c}{ Process Parameters } & \multicolumn{1}{c}{ Value } \\
\hline $\begin{array}{l}\text { Absolute pressure on } \\
\text { sample (psia) }\end{array}$ & 15.21 \\
$\begin{array}{l}\text { Pressure on sample line } \\
\text { (MPa-g) }\end{array}$ & 0.04 \\
$\mathrm{H}_{2}$ gas flow rate $(\mathrm{ml} / \mathrm{min})$ & $50-60$ \\
Methanol testplant & $0.3-0.4$ \\
pressure (MPa-g) & $220^{\circ} \mathrm{C}$ \\
Reactor temperature & $220^{\circ} \mathrm{C}$ \\
Pre-heater line & $60^{\circ} \mathrm{C}$ \\
temperature & \\
Sampling line temperature &
\end{tabular}

Figure 14 below shows the correlation between the water content and the pressure of the methanol testplant during the catalyst activation.

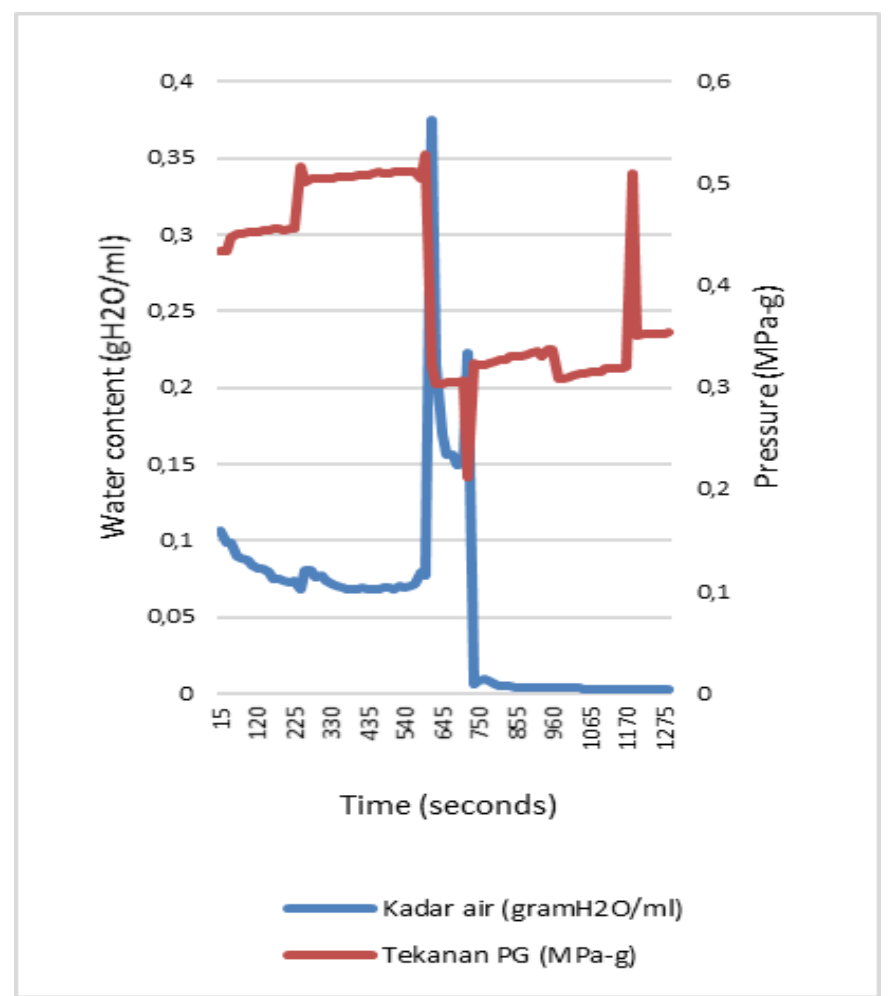

Figure 14.

Water Content and Pressure Variation during Catalyst Activation Process

Water was formed as the product of a reaction between hydrogen gas with oxygen molecules of the catalyst. The amount of water will be decreased along with the time of the process. Pressure decrease on the methanol testplant is caused by hydrogen gas out of supply. 
Hydrogen gas cylinder also contains some moisture as a buffering element. Hydrogen has a lower molecular weight compared to water [14], so the water molecules will remain in the cylinder until the hydrogen runs out. At that time, the water molecules will be released from the cylinder and entering the methanol test plant. It will cause a significant increase on water content of the gas.

The other possible cause is the diurnal effect in the stainless-steel pipe (tubing). The water molecules will be adsorbed on the rough surfaces of the wet wall pipe due to water molecule polarity. In the daylight, the increasing ambient temperature and the sunlight will promote the water molecules to be desorbed from the pipe surfaces and entering the gas flow. It will increase the water content of the gas and caused the increased water content reading on the gas analyser [15].

The surfaces of stainless-steel tubing also contain some iron oxide, which will adsorb water and hydrogen sulfide molecules. The alternative solution to overcome this problem is using electropolished stainless steel tubing, which has smoother surfaces, less reactive toward the water molecules, and has a higher chromium oxide ratio compared to other iron oxides.

The other more practical solutions are using an additional heater on the pipeline and adjusting the closer distance between the sampling point and the moisture analyser [16]. Note that hydrogen gas cylinder has to be replaced immediately with the new one when the pressure of the cylinder is already low.

\section{Methanol Synthesis After Catalyst Activation Process}

Methanol synthesis can be conducted on the methanol test plant after the water content of the gas approaches zero. In this research, the catalyst activation was carried out for a total of 30 hours. The samplings of the gas product are done at 1-hour sampling period using a gas sampling bag. The gas product is analysed to gather the methanol concentration on gas product data.

Table 11 shows the process parameters of the methanol synthesis process. Figure 15 shows the methanol concentration in the gas product during 300 minutes of reaction.

Table 11

Process Parameters of the Methanol Synthesis Process

Process Parameters Value

\begin{tabular}{lc}
\hline $\begin{array}{l}\text { Absolute pressure on the } \\
\text { sample line (psia) }\end{array}$ & 15.21 \\
Pressure on the sample line & \\
(MPa-g) & 0.04 \\
$\mathrm{H}_{2}$ gas flow rate (ml/min) & $50-60$ \\
Pressure on methanol & $0.3-$ \\
testplant (MPa-g) & 0.4 \\
Reactor temperature & $260^{\circ} \mathrm{C}$ \\
Pre-heater line temperature & $260^{\circ} \mathrm{C}$ \\
Sampling line temperature & $60^{\circ} \mathrm{C}$ \\
\hline
\end{tabular}

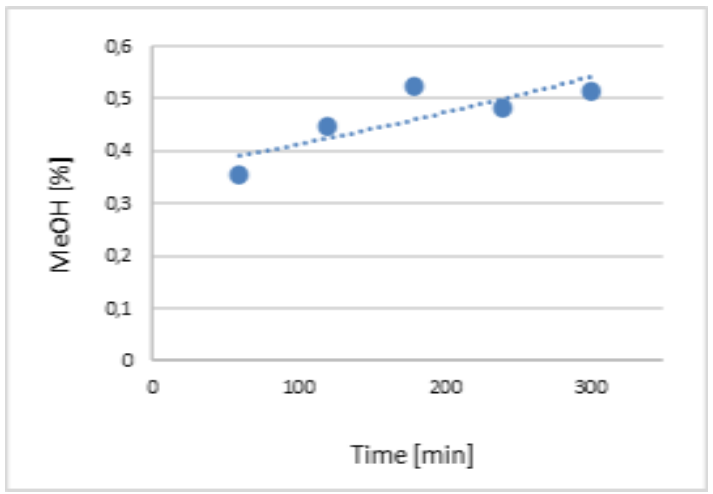

Figure 15.

Methanol Concentration in the Gas Product against Time

From Figure 15 above, it was found that methanol concentration increased as the time of methanol synthesis went on. Therefore, it can be concluded that the catalyst is active in the methanol synthesis reaction. To increase methanol product concentration, reactor length can be extended so the reaction and contact time can be longer.

\section{CONCLUSION}

The temperature controlling process on the reduction process as part of the catalyst activation step on methanol synthesis is conducted using a simple configuration of sensors, controllers, and actuators. The applied temperature controlling system was able to respond well to setpoint change, indicated by the fluctuation of the process variables that are still within the steady-state error criteria of $2 \%$ and the response time that is within $60-120$ seconds.

The system also responds well toward load change, in this case, the flow rate changes up to $500 \mathrm{ml} / \mathrm{min}$. The fluctuation of the process variables is still within the steadystate error criteria of $2 \%$. Therefore, the system considered to be able to respond well toward the disturbance rejection.

The application of the temperature controlling system both on the catalyst activation step and the methanol synthesis step show satisfying results. The system is 
capable to keep the stability of operating conditions in the catalyst reduction step at $220^{\circ} \mathrm{C}$ with the hydrogen gas flow rate variation. At the end of the process, methanol products were formed from syngas, indicating catalyst activation step was carried out successfully. The concentration of methanol in gas products was up to $0.5 \%$-volume.

\section{AUTHOR INFORMATION}

Arya Bhaskara Adiprabowo, S.T.

arya.bhaskara@bppt.go.id; (021) 75791355

\section{Author Contributions}

First Author has contributed for setting \& testing of Instrument and Control equipment and writing for Instrument, Control, Result and Discussion section. Second Author has contributed for writing of Process Description, Introduction and Material \& Methods section. Third Author has contributed for P\&ID Drawing, Material \& Methods and Conclusion section, and also correcting the draft paper content. Fourth Author has contributed to Mechanical \& Piping assembling and testing of the plant. All authors has contributed to conducting the testing, commissioning and doing experiment in the laboratorium.

\section{ACKNOWLEDGMENT}

Authors would like to thank Bioenergy Program 2019 and SATREPS Program 2014 -2019 for financially supporting this research.

\section{REFERENCES}

[1] Sharma, S., Gupta, S., et.al., Selection and Application of Advance Control System: PLC, DCS and PC-Based System, Journal of Scientific \& Industrial Research, Vol. 64, 2005, pp.249-255.

[2] Lo, I.C., and Wu, H.S., Methanol Formation from Carbon Dioxide Hydrogenation using $\mathrm{Cu} / \mathrm{ZnO} / \mathrm{Al}_{2} \mathrm{O}_{3}$ Catalyst, Journal of the Taiwan Institute of Chemical Engineers, Vol.98, 2019, pp.124-131.
[3] Lucking, L.E., Methanol Production from Syngas: Process Modelling and Design Utilising Biomass Gasification and Integrating Hydrogen Supply, Thesis, Delft University of Technology, Netherlands, 2017.

[4] Sorace, R.E., Reinhardt, V.S., and Vaughn, S.A., High-Speed Digital-toRF Converter, U.S. Patent 5668842, 1997.

[5] Hendriyana, Susanto, $H_{\text {., }}$ and Subagjo, Kinetika Reduksi Isotermal CuO/ZnO dalam Penyiapan Katalis untuk Sintesis Metanol, Prosiding Seminar Nasional Teknik Kimia Kejuangan, ISSN 1693-4393, 2015.

[6] ASME B31.3, Process Piping, American Society of Mechanical Engineer, 2012.

[7] Prasetya, E., Regenerasi Katalis Campuran $\mathrm{Al}_{2} \mathrm{O}_{3}$ dan $\mathrm{HZSM}-5$ Melalui Reaksi Oksidasi Berbasis Udara Bebas Dari Reaksi Etanol Menjadi Hidrokarbon, Skripsi, Universitas Indonesia, 2012.

[8] Cigoy, D., How to Select the Right Temperature Sensor, Keithley Instruments, Inc., Cleveland, 2007.

[9] KH-15 Pressure Transmitter Data Sheet, Nagano Keiki, Tokyo, Japan.

[10] Ogata, K., Modern Control Engineering, 5th Edition, Prentice Hall, New Jersey, 2010.

[11] Seborg, D., Process Dynamics and Control, John Wiley \& Sons, Inc., New York, 2004.

[12] E5CB Temperature Controller Manual, Omron Europe, Amsterdam, Netherland.

[13] Setiawan, I., Kontrol PID Untuk Proses Industri, Elex Media Komputindo, 2008.

[14] Safetygram 4: Gaseous Hydrogen, Air Products, Pennsylvania, USA.

[15] Trace Moisture Diurnal Effects in Process Applications, GE Sensing \& Inspection Technologies, Massachusetts, USA.

[16] Harris, P.,and Pellegrini, M., Mass Transport in Sample Transport Lines Adsorption Desorption Effects and Their Influence on Process Analytical Measurements, HariTec, 2004. 